\title{
Strategies among phytoplankton in response to alleviation of nutrient stress in a subtropical gyre
}

\author{
Robert H. Lampe $\mathbb{C}^{1,2} \cdot$ Seaver Wang $\mathbb{D}^{3} \cdot$ Nicolas Cassar $\mathbb{1}^{3,4} \cdot$ Adrian Marchetti $\mathbb{( D}^{2}$
}

Received: 24 January 2019 / Revised: 7 July 2019 / Accepted: 2 August 2019 / Published online: 22 August 2019

(c) The Author(s), under exclusive licence to International Society for Microbial Ecology 2019

\begin{abstract}
Despite generally low primary productivity and diatom abundances in oligotrophic subtropical gyres, the North Atlantic Subtropical Gyre (NASG) exhibits significant diatom-driven carbon export on an annual basis. Subsurface pulses of nutrients likely fuel brief episodes of diatom growth, but the exact mechanisms utilized by diatoms in response to these nutrient injections remain understudied within near-natural settings. Here we simulated delivery of subsurface nutrients and compare the response among eukaryotic phytoplankton using a combination of physiological techniques and metatranscriptomics. We show that eukaryotic phytoplankton groups exhibit differing levels of transcriptional responsiveness and expression of orthologous genes in response to release from nutrient limitation. In particular, strategies for use of newly delivered nutrients are distinct among phytoplankton groups. Diatoms channel new nitrate to growth-related strategies while physiological measurements and gene expression patterns of other groups suggest alternative strategies. The gene expression patterns displayed here provide insights into the cellular mechanisms that underlie diatom subsistence during chronic nitrogen-depleted conditions and growth upon nutrient delivery that can enhance carbon export from the surface ocean.
\end{abstract}

\section{Introduction}

A defining characteristic of subtropical gyre ecosystems is low biological productivity, but as vast expanses that cover $40 \%$ of the Earth's surface, these regions have a significant role in primary production and biogeochemical cycling [1].

Supplementary information The online version of this article (https:// doi.org/10.1038/s41396-019-0489-6) contains supplementary material, which is available to authorized users.

Adrian Marchetti

amarchetti@unc.edu

1 Integrative Oceanography Division, Scripps Institution of Oceanography, University of California, San Diego, La Jolla, CA, USA

2 Department of Marine Sciences, University of North Carolina at Chapel Hill, Chapel Hill, NC, USA

3 Division of Earth and Ocean Sciences, Nicholas School of the Environment, Duke University, Durham, NC, USA

4 Laboratoire des Sciences de l'Environnement Marin (LEMAR), UMR 6539 UBO/CNRS/IRD/IFREMER, Institut Universitaire Européen de la Mer (IUEM), Brest, France
The Sargasso Sea in the North Atlantic Subtropical Gyre (NASG) is one such region that has been extensively studied via the Bermuda Atlantic Time Series (BATS) [2]. Here, as in much of the low latitude oligotrophic ocean, nitrogen is often the limiting nutrient for phytoplankton growth with surface nitrate typically measured in nanomolar concentrations [3, 4].

Despite this pervasive nitrogen limitation, some estimates of net community production (NCP), i.e. carbon export potential, in the NASG are surprisingly high $(>3.0$ $\pm 1.0 \mathrm{~mol} \mathrm{C} \mathrm{m}^{-2}$ year $^{-1}$ ) and similar to those in regions with a more regular supply of nutrients [5-7], although measured carbon export is only $43-77 \%$ of these NCP estimates $[8,9]$. Export of organic matter in the NASG appears to have significant contributions from diatoms as evidenced by estimates that they can account for $>30 \%$ of the annual particulate organic carbon export at BATS and by the presence of intact healthy diatom cells in the deep ocean [10-12]. In general, diatoms are anticipated to be substantial contributors to carbon export as a result of their heavy siliceous cell walls, but such high contributions to export are unexpected in the NASG given that diatoms are considered to be responsible for $<5 \%$ of regional chlorophyll concentrations $[2,13]$. 
Although diatoms are typically in low abundances, the historical record at BATS indicates that diatom blooms occur periodically $[2,14,15]$. As with the surprisingly high estimates of NCP, the mechanism for nutrient supply that would fuel such blooms remains unresolved [9]. Nitrogen $\left(\mathrm{N}_{2}\right)$ fixation by diazotrophs may introduce new nitrogen into the system, but the measured rates of $\mathrm{N}_{2}$ fixation are much lower than needed to support NCP estimates [16-18]. New nitrogen can also be introduced via atmospheric deposition; however, these fluxes are also relatively low $[19,20]$. Passage of winter storms is believed to cause entrainment of nitrate into the euphotic zone, but the most intense diatom blooms have been recorded in the late spring or summer suggesting that the two are not linked $[2,21]$.

Wind-induced vertical mixing has been shown to increase surface nitrate concentrations and fuel diatom blooms in the spring [15]. Other mechanisms of vertical supply such as eddy pumping and frontal features are also likely significant sources of nitrate [8, 22]. Estimates of these upward nitrate fluxes are calculated to be sufficient to support rates of primary production in the Sargasso Sea, and although these sources show seasonal variation, summertime upward fluxes are still observed [23]. Furthermore, isotopic signatures of small eukaryotic phytoplankton during the summertime indicate consumption of nitrate originating from the subsurface rather than a reliance on recycled nitrogen; therefore, a summertime supply of nitrate to fuel diatom growth is possible $[5,24]$.

Diatoms are believed to have superior abilities to take up and store nitrate, allowing them to outcompete other phytoplankton groups [12, 25-29]. Molecular studies on nitrogen limitation in diatoms have shown a transcriptional pattern among diatoms that consists of carbon metabolism restructuring and increased nitrogen recycling [30-33]; however, these studies have primarily focused on monocultures under laboratory conditions, particularly model organisms, which may not accurately represent the natural environment. Patterns in gene expression within a plankton community under near-natural conditions in an oligotrophic subtropical gyre have rarely been examined. Alexander et al. [34] showed there are transcriptional differences among phytoplankton groups, but these differences in expression of specific genes and metabolic pathways remain mostly uncharacterized.

To investigate unique strategies diatoms may be using for survival under oligotrophic conditions followed by rapid growth when nutrients are introduced and to compare these strategies to those of other eukaryotic phytoplankton groups, we artificially simulated delivery of subsurface nutrients by mixing near-surface seawater with filtered, nutrient-replete deep seawater (DSW) collected in the Sargasso Sea. Gene expression within each group was examined via comparative metatranscriptomics after $48 \mathrm{~h}$ of incubation. We substantiate that diatoms are highly transcriptionally responsive to such pulses from depth compared to other dominant phytoplankton groups and provide evidence that eukaryotic phytoplankton have differing strategies for nitrate use.

\section{Materials and methods}

\section{Experimental design}

DSW amendment experiments were conducted in the Sargasso Sea onboard the R/V Atlantic Explorer at $27^{\circ} 25.693^{\prime}$ $\mathrm{N} 76^{\circ} 26.244^{\prime} \mathrm{W}$ (Site 1) on August 7, 2016 and at $31^{\circ}$ $58.821^{\prime} \mathrm{N} 74^{\circ} 56.514^{\prime} \mathrm{W}$ (Site 2) on August 10, 2016 (Fig. 1). At $\sim 06: 00$ ADT (UTC-3) on both days, nearsurface seawater $(5 \mathrm{~m})$ and DSW $(600 \mathrm{~m})$ were collected using $12 \mathrm{~L}$ Niskin bottles on a CTD rosette. Near-surface water was immediately transferred to $10 \mathrm{~L}$ Cubitainers ${ }^{\circledR}$ (Hedwin Corporation, Newark, DE, USA) and subsampled for the initial time point (T0). Cubitainers were cleaned prior to the incubations by soaking the inside walls in 1.2 $\mathrm{mol} \mathrm{L}{ }^{-1} \mathrm{HCl}$ for 3 days followed by three rinses with Milli$\mathrm{Q} \mathrm{H}_{2} \mathrm{O}$ and a rinse with near-surface seawater. For the incubations, $5 \mathrm{~L}$ of unfiltered near-surface seawater was dispensed into all cubitainers. The remaining $5 \mathrm{~L}$ for each cubitainer was either filtered near-surface seawater or filtered DSW that was passed through a $0.2 \mu \mathrm{m} / 0.2 \mu \mathrm{m}$ AcroPak 1000 that had been pre-rinsed with surface seawater. All incubations were conducted in triplicate.

Cubitainers were incubated in an on-deck surface seawater flow-through system maintained at ambient surface temperatures and covered with neutral density screening to reduce irradiance to $\sim 33 \%$ of the incident irradiance. Temperatures from inside the incubators and on-deck irradiance values are provided in Fig. S1. To prevent the ship's deck lights from affecting the incubations, the incubators were covered with an opaque tarp after sunset until just before sunrise. After $48 \mathrm{~h}$ of incubation, subsamples from each cubitainer were collected for dissolved macronutrients, chlorophyll, nitrate uptake rates, and RNA. Additional materials and methods are available in the Supplementary Information.

\section{RNA sequencing and analysis}

Approximately $6.4 \mathrm{~L}$ from each cubitainer were filtered using a peristaltic pump onto $0.8 \mu \mathrm{m}$ Pall Supor $^{\circledR}$ polyethersulfone filters $(142 \mathrm{~mm})$, which were immediately flash frozen in liquid nitrogen then stored at $-80{ }^{\circ} \mathrm{C}$. RNA was extracted using the ToTALLY RNA Total RNA Isolation Kit and then treated with DNase 1 (Life Technologies, Grand Island, NY, USA). The extraction procedure 
Fig. 1 Map of locations for seawater collection with a satellite-derived chlorophyll $a$ and $\mathbf{b}$ sea surface temperature (SST). Satellite data are 8-day averages centered on August 9, 2016 and obtained from the NOAA Coastwatch Browser. White areas indicate no data as a result of cloud cover
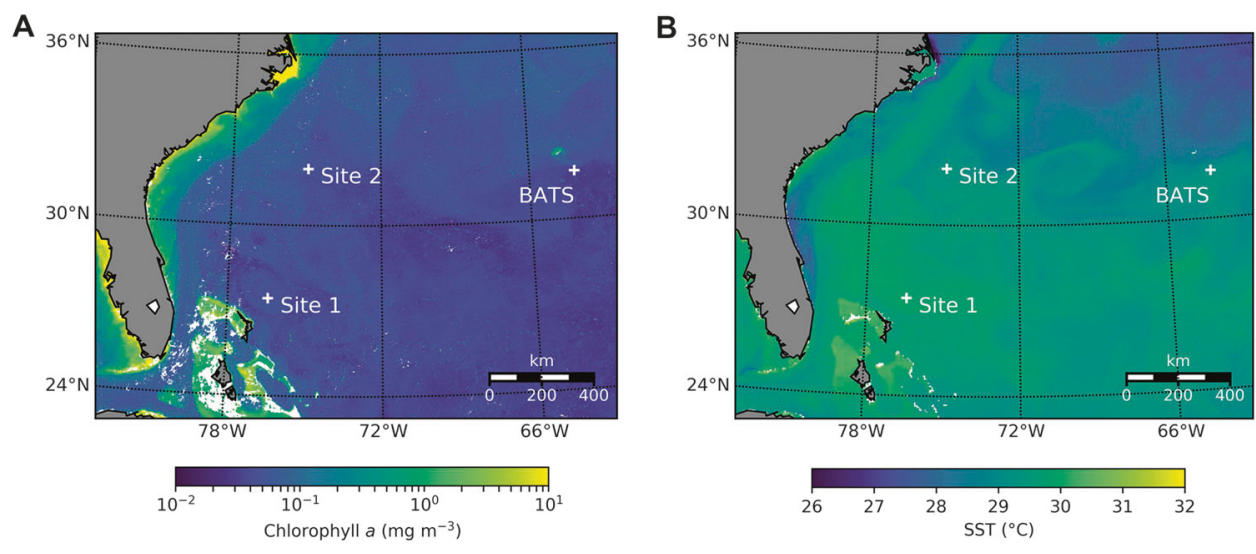

followed the manufacturer's instructions with an additional glass bead beating step first to assist with cell lysis. For the initial time point (T0), total RNA from triplicate filters were pooled into a single sample. Due to low RNA yields, RNA was linearly amplified using the MessageAmp ${ }^{\mathrm{TM}}$ Premier RNA Amplification Kit (Catalog no. AM1792, Invitrogen, Carlsbad, CA, USA). RNA quantity and purity were assessed prior to sequencing on an Agilent Bioanalyzer 2100. Library prep was then conducted with the KAPA Stranded mRNA-Seq kit for Illumina platforms then sequenced on two lanes on the Illumina HiSeq 2500 platform at the High-Throughput Sequencing Facility at the University of North Carolina at Chapel Hill. One lane was run in high output mode with $100 \mathrm{bp}$ paired-end reads to generate more reads and the other was run in rapid run mode with 150 bp paired-end reads to generate longer reads. Triplicate samples were sequenced for both treatments from Site 1 whereas duplicates were sequenced from Site 2 (Dataset S1).

Reads were assembled de novo using Trinity v2.5.1 with the default options for quality trimming via trimmomatic $[35,36]$. Contigs were clustered based on $99 \%$ similarity with CD-HIT-EST [37]. Taxonomic annotation of contigs was assigned by best homology (lowest $E$-value) to sequences in PhyloDB v1.076 [38] using BLASTX v2.7.1 $\left(E\right.$-value $\left.\leq 10^{-5}\right)$. To assign gene function to contigs, the same methodology was used with the Kyoto Encyclopedia of Genes and Genomes (KEGG, Release 86) [39]. KEGG Ortholog (KO) annotations were assigned from the top hit with a KO annotation from the top 10 hits (https://github. com/ctberthiaume/keggannot).

Taxonomically annotated contigs were used to construct an index and trimmed reads were mapped using Salmon v0.9.1 with GC bias correction to generate transcripts per million (TPM) and read number estimates per contig [40]. TPM were used to quantify relative taxonomic proportions. To assess differential expression, read number estimates were summed based on $\mathrm{KO}$ number within each taxonomic group. For contigs with no KO number, read number estimates were summed by the KEGG gene definition. Normalized gene abundances, fold change values, and Benjamini-Hochberg adjusted $P$-values were calculated using DESeq2 v1.18.1 [41]. Genes were considered significantly differentially expressed if the adjusted $p$-value was $<0.05$.

\section{Statistical analyses}

Two-way ANOVAs followed by Tukey tests for multiple comparisons were performed on the biological and chemical properties of the seawater (non-gene expression data) in Graphpad PRISM v8.00.

\section{Data deposition}

The sequence data reported in this study have been deposited in the National Center for Biotechnology (NCBI) sequence read archive. RNA sequences are under the accession no. SRP172750 (Bioproject accession no. PRJNA508539), and rDNA sequence data are under the accession no. SRP126177 (Bioproject accession no. PRJNA421139). Assembled contigs, read counts, and annotations are available at Zenodo (https://doi.org/10. 5281/zenodo.2538206).

\section{Results and discussion}

\section{Phytoplankton community responses to DSW amendments}

Initial dissolved nitrate plus nitrite concentrations from the near surface seawater were $0.27 \pm 0.27 \mu \mathrm{mol} \mathrm{L}^{-1}$ at Site 1 and below the detection limit $\left(<0.007 \mu \mathrm{mol} \mathrm{L}{ }^{-1}\right)$ at Site 2 (Fig. 2). Relative to the other macronutrients, these low nitrate concentrations suggest that the initial phytoplankton communities were likely nitrogen limited as anticipated for the region [2]. Silicic acid concentrations are normally 
Fig. 2 Macronutrient concentrations for the initial surface and deep seawater and following $48 \mathrm{~h}$ of incubation (surface and deep seawater [DSW] amendment treatments) at both experimental sites. Error bars represent the standard deviation of the mean $(n=3)$, except the initial deep seawater from $600 \mathrm{~m}$ where $n=1$. bd below detection limit
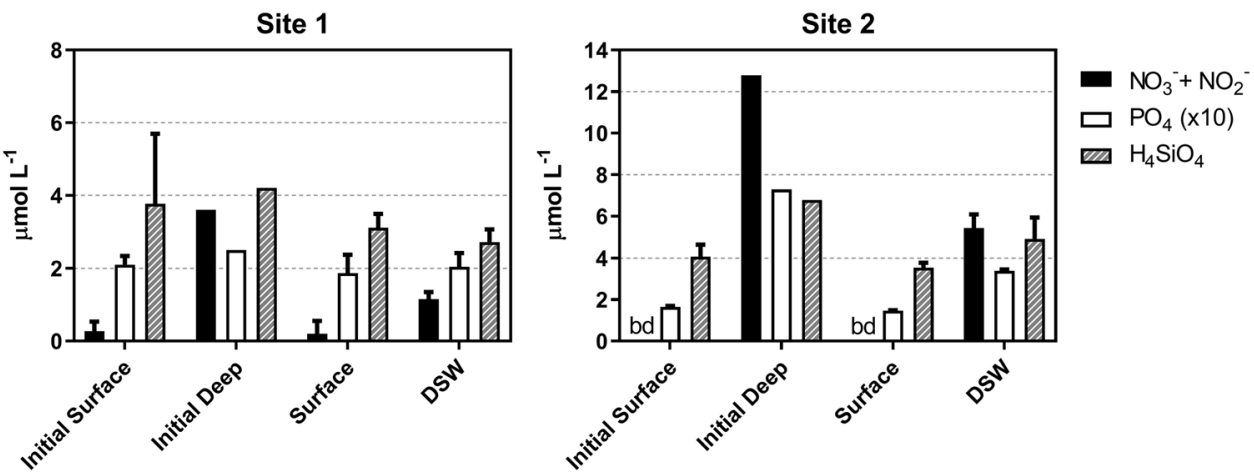

depleted to $0.5-1 \mu \mathrm{mol} \mathrm{L} \mathrm{L}^{-1}$ at BATS; however, initial

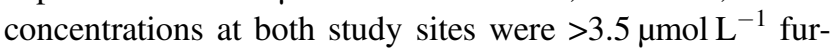
ther indicating that nitrate rather than silicic acid was limiting to diatom growth [42]. Dissolved iron concentrations were $1.42 \mathrm{nmol} \mathrm{L}^{-1}$ at Site 1 and $1.21 \mathrm{nmol} \mathrm{L}^{-1}$ suggesting that iron limitation or stress in the initial community was unlikely [43]. The initial chlorophyll $a$ concentrations at both sites were low $(0.04 \pm 0.01$ and $0.05 \pm 0.00$ for Sites 1 and 2 , respectively) which were also anticipated for the region [8] and were further diluted by $50 \%$ with the filtered seawater additions (Fig. 3a). The majority of chlorophyll belonged to the large $(>5 \mu \mathrm{m})$ size-fraction.

DSW nitrate concentrations at both sites were likely much higher than would be anticipated for a pulse of new nitrogen even after dilution by $50 \%$ (Fig. 2) [3]. By averaging the initial nitrate concentrations from the seawater at both depths, estimates of the starting concentrations for the DSW treatment were $1.94 \mu \mathrm{mol} \mathrm{L}^{-1}$ at Site 1 and $6.39 \mu \mathrm{mol}$ $\mathrm{L}^{-1}$ at Site 2. Addition of this filtered nutrient-rich DSW and incubating for $48 \mathrm{~h}$ resulted in a significant increase $(P$ $<0.0001)$ in chlorophyll from the large $(>5 \mu \mathrm{m})$ sizefraction. In addition, particulate nitrogen in both size fractions increased albeit not always significantly (Fig. 3b). Interestingly although chlorophyll $a$ concentrations were normally higher in the large size-fraction, particulate nitrogen and nitrate uptake rates were greater in the small size-fraction $(<5 \mu \mathrm{m})$ (Fig. 3b, c).

Nitrate uptake was significantly higher within each size fraction in the DSW treatments apart from the small size fraction at Site 1. Due to the low initial nitrate concentrations at both sites in the initial seawater and surface treatments, the tracer addition of $0.1 \mu \mathrm{mol} \mathrm{L}{ }^{-115} \mathrm{NO}_{3}$ to measure uptake may have alleviated some nitrate limitation; thus, these measurements are more reflective of a potential uptake rate rather than actual nitrate uptake [44]. This influence is apparent in comparisons to previous measurements during oligotrophic conditions $\left(<1 \mathrm{nmol} \mathrm{L}^{-1} \mathrm{day}^{-1}\right)$ as rates in the initial or surface treatments were much higher in this study [3]. The measured rates from the DSW treatments, however, are similar when compared to those obtained during bloom periods (10-150 $\left.\mathrm{nmol} \mathrm{L}^{-1} \mathrm{day}^{-1}\right)$ [3].
Biomass-specific nitrate uptake rates $\left(V_{\mathrm{NO} 3}\right)$ were also higher $(P<0.001$ except in the $<5 \mu$ m community at Site 1$)$ in both size fractions in the DSW treatment with larger phytoplankton displaying significantly higher $V_{\mathrm{NO} 3}$ due to higher biomass (i.e., particulate nitrogen concentrations) in the small size fraction. Small eukaryotes have been shown to have an affinity for nitrate ( $>50 \%$ of $\mathrm{N}$ quota) while prokaryotic phytoplankton continue to mostly rely on regenerated forms of nitrogen. Although Synechococcus populations under similar conditions have shown a high affinity for nitrate [45], a significant proportion of the observed nitrate uptake in our experiments can likely be attributed to eukaryotic phytoplankton [5, 24, 46]. These results indicate that both large $(>5 \mu \mathrm{m})$ and small $(<5 \mu \mathrm{m})$ phytoplankton may have a preference or reliance on new forms of nitrogen with a potentially greater affinity for nitrate in larger cells.

Detrital material has been shown to account for $25 \%$ of the bulk particulate nitrogen under similar conditions [24], and thus, it could be elevating the particulate nitrogen measurements reducing $V_{\mathrm{NO} 3}$ in the smaller size fraction. However, nitrate uptake was also greater for smaller cells, indicating that the newly available dissolved nitrate must have been assimilated into particulate nitrogen. Some of the nitrate uptake in the small size fraction may be attributed to heterotrophic bacteria which can account for $15 \%$ of the bulk particulate nitrogen $[24,47,48]$. It is also possible that the small cells were more effectively grazed as is common in incubation experiments [49], and chlorophyll became uncoupled as particulate nitrogen may be shifted to small nonchlorophyll-containing particles, although grazing rates were likely significantly impacted by the $50 \%$ dilution [50]. Alternatively, this high level of nitrogen unmatched by chlorophyll could be explained by nitrogen storage. Evidence of nitrate storage has been reported across major eukaryotic phytoplankton lineages [51], and uptake of nitrate that is then stored rather than immediately utilized for growth would be consistent with the observation of nitrate uptake and increased particulate nitrogen unmatched by increases in chlorophyll. 
Fig. 3 Biomass and $\mathrm{NO}_{3}$ uptake measurements from the initial surface seawater and incubations following $48 \mathrm{~h}$ for the $>5 \mu \mathrm{m}$ (black) and $<5 \mu \mathrm{m}$ (white) phytoplankton community at sites 1 (left) and 2 (right): a Chlorophyll $a$ ( $\mu \mathrm{g}$ $\left.\mathrm{L}^{-1}\right)$, b Particulate nitrogen ( $\mathrm{PN}$, nmol L $\left.{ }^{-1}\right)$, c Absolute nitrate $\left(\mathrm{NO}_{3}{ }^{-}\right)$uptake rates $\left(\rho, \mathrm{NO}_{3}{ }^{-}\right.$ taken up per day), d Biomassspecific nitrate uptake rates $\left(V_{\mathrm{NO} 3}\right)$, i.e. nitrate uptake rates normalized to particulate nitrogen (nmol N L ${ }^{-1} \mathrm{day}^{-1}$ / nmol $\mathrm{N} \mathrm{L}^{-1}$ or day ${ }^{-1}$ ). Error bars represent the standard deviation of the mean $(n=3)$
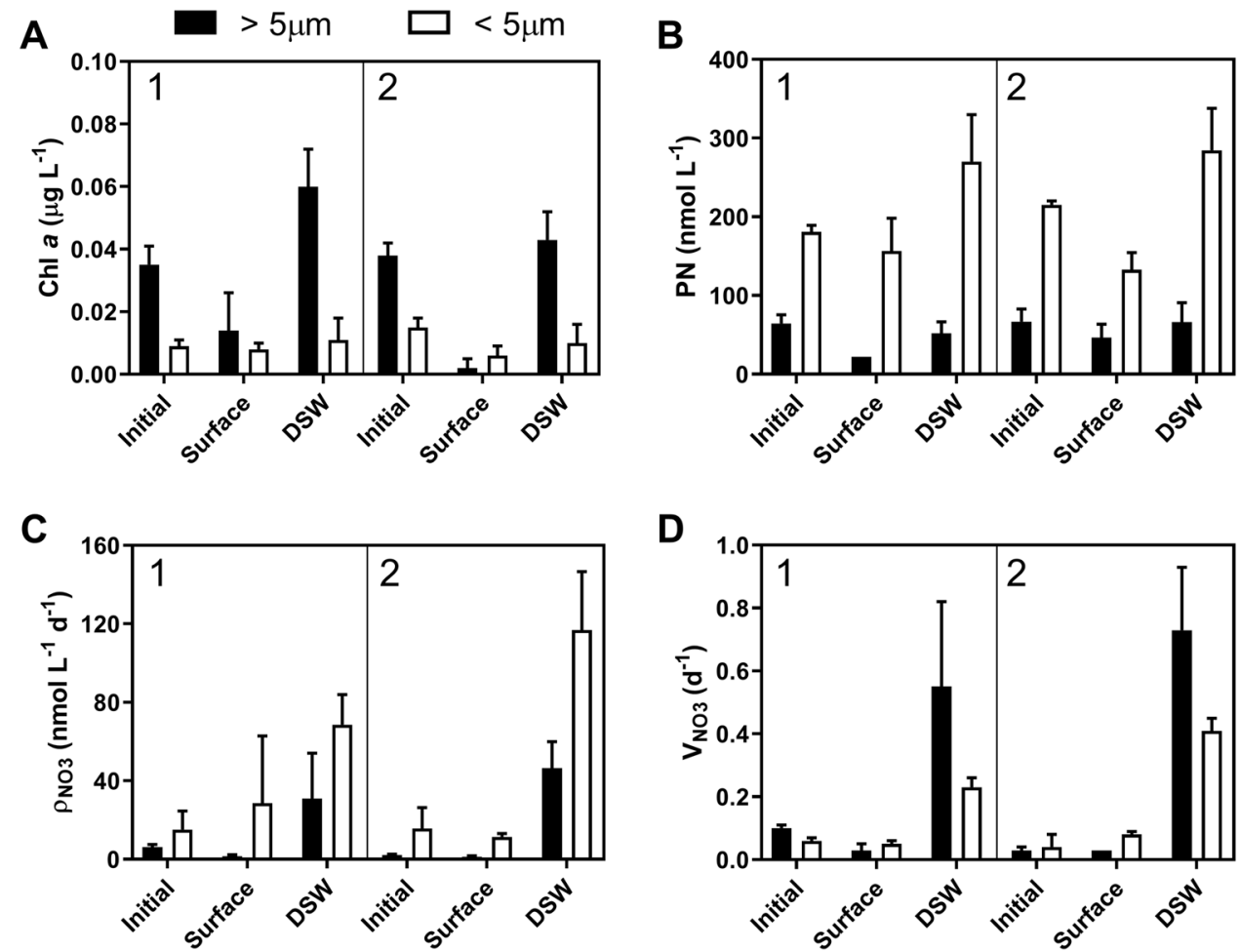

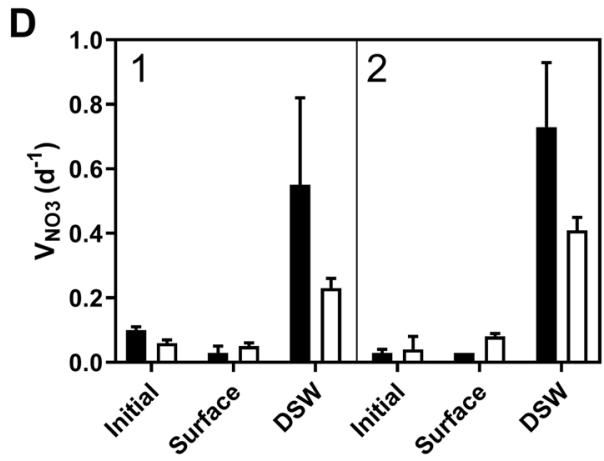

\section{Taxonomic composition}

The relative abundance of TPM were examined to assess the changes in the taxonomic composition of the eukaryotic community following DSW amendment (Fig. 4). The initial communities' transcript pools at both sites were dominated by dinoflagellates with increases in their relative proportions following $48 \mathrm{~h}$ of incubation in the surface treatment (Fig. S2). This relatively high dinoflagellate presence in the initial seawater is supported by V4-18S ribosomal DNA (rDNA) amplicon sequencing results (Dataset S2, Fig. S2). Dinoflagellates have previously been found to be a major constituent of the protistan community in the euphotic zone of the Sargasso Sea [52], and mixotrophic dinoflagellates are likely able to outcompete other eukaryotic phytoplankton under oligotrophic conditions [53]. Of the dinoflagellates resolved to a genus level, the top three genera at both sites were Gyrodinium, Neoceratium, and Karlodinium, all of which are known to contain species that exhibit mixotrophy (Fig. S3) [53, 54].

Haptophytes were the second most abundant group in the initial community (Figs. 4 and S2) and mostly comprised of Prymnesiales, consistent with previous observations in the region (Dataset S2, Fig. S4) [14, 55]. Prasinophytes were the third most abundant group based on the 18S rDNA, although less abundant than diatoms based on RNA (Figs. 4 and S2). Most Prasinophyte OTUs did not resolve to a SILVA family-level assignment; however, the most abundant with annotation belong to clade IX, which entirely consists of uncultured environmental sequences and have been shown to dominate warm oligotrophic oceanic waters (Fig. S5) [56, 57]. The prevalent prasinophyte genera with annotations were Pyramimonas and Dolichomastix, the latter of which have also been associated with oligotrophic surface waters (Dataset S2) [56].

Less than $8 \%$ of the transcripts were attributed to diatoms in the surface treatments which is consistent with estimates via pigment analysis that show diatom contributions to total chlorophyll biomass are commonly low [2]. Diatoms comprised even lower relative abundances $(<1 \%)$ of the V4$18 \mathrm{~S}$ rDNA suggesting that their proportion of the initial eukaryotic community may have been even lower than that estimated via transcripts (Fig. S2). Initial diatom abundances via quantitative rDNA were $4.34 \times 10^{6}$ (Site 1) and $7.38 \times 10^{6}$ (Site 2) copies $\mathrm{L}^{-1}$, which were similar but above average compared to values obtained throughout the Sargasso Sea during the study period (Fig. S6). The dominant diatom taxa included Chaetoceros, Pseudo-nitzschia, and Ditylum (Fig. S7), the former two genera having previously been reported to be common at BATS [14, 58]. Chaetoceros can form diatom-diazotroph associations (DDAs), which likely confers an advantage under nitrogen-limiting conditions [59].

Following incubation with DSW, diatoms became the dominant eukaryotic phytoplankton group with $34 \%$ of the transcripts at both sites. At BATS, diatom blooms are infrequent but have been previously observed [14, 15, 60-62], and the increase in diatoms observed here was anticipated due to 
Fig. 4 Average proportion of transcripts per million (TPM) in the surface and deep seawater (DSW) treatments for the five most dominant eukaryotic phytoplankton groups at both sites

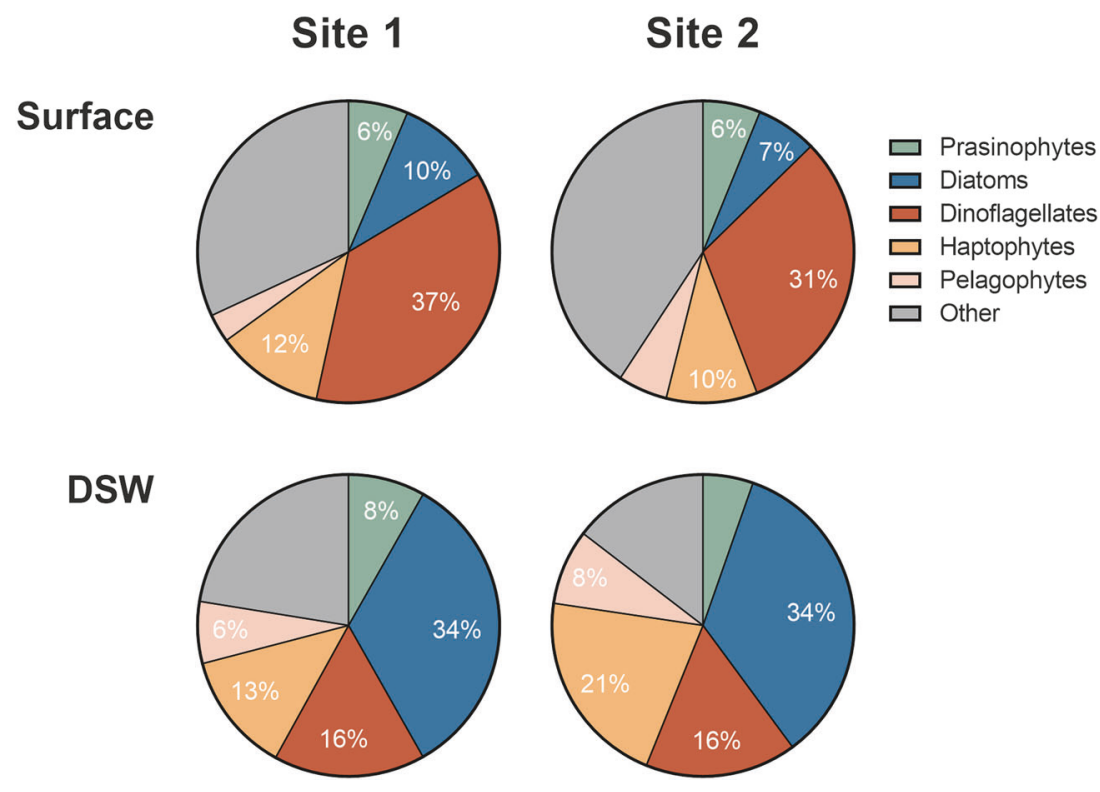

diatom's known ability to grow rapidly in nutrient-replete conditions $[63,64]$. An increase in diatoms was also observed in a similar metatranscriptomic study in the North Pacific Subtropical Gyre (NPSG) [34], where occasional diatom blooms are observed indicating that these characteristic responses may apply across similar ocean basins, although the conditions under which diatom blooms occur in the two gyres may differ $[65,66]$.

\section{Transcriptional responses among phytoplankton groups}

The total number of genes overrepresented in either treatment (surface or DSW) for each of the four dominant functional groups were examined (Fig. 5a). At both sites, diatoms increased expression of a majority of their genes in the DSW treatment. Dinoflagellates showed an opposite trend with more genes overrepresented in the surface treatment. Results were inconsistent across the two sites for prasinophytes and haptophytes.

These distributions indicate that the two diatom communities here were highly transcriptionally active following nutrient amendment relative to the nutrient-depleted surface conditions which is consistent with what has been observed under similar incubations in the NPSG [34] and in response to being upwelled [27]. It has also been suggested that these transcriptional distributions are a reflection of $\mathrm{r}$ - and $\mathrm{K}$ selection [34]. Given the observed responsiveness and increase in diatom abundances, both the experiments performed in this study align with this paradigm. Interestingly, dinoflagellates showed little change in expression in the NPSG, in contrast to this study, where higher transcriptional activity was observed under surface conditions. Numerous differences in the experiments, such as timing of sampling may contribute to this discrepancy. It has also been suggested that dinoflagellates have comparatively less regulation of gene expression with transcription [67]; however, studies have shown differential expression of many genes in dinoflagellates under certain environmental conditions [68-70]. Higher transcriptional activity here may be linked to their speculated mixotrophic behavior under the ambient oligotrophic conditions.

The expression of genes with matching KEGG Orthology (KO) annotation among these four dominant algal groups were queried to examine similarities or differences in transcription of conserved genes under both conditions. Orthologs normally retain the same function throughout evolutionary history allowing for direct comparisons in transcription among the taxonomic groups. 1004 genes were found to be expressed by all four of the dominant eukaryotic phytoplankton groups in both experiments (Fig. 5b, Dataset S3). These genes were sorted based on the variance expression of the gene among the groups compared to the average variance of the dataset and which group displayed the highest fold change values. A majority of the genes showed relatively little change in expression among the groups and are involved in a wide array of processes including glycolosis, amino acid biosynthesis, photosynthesis, and ribosomal proteins. No genes were found to be consistently overrepresented (absolute $\log _{2}$-fold change $>2$ ) among all four groups in either the surface or DSW treatments.

In concordance with diatoms' increased transcription of more genes following DSW amendment, diatoms had the largest number of uniquely overrepresented orthologs (193 KOs; Fig. 5b), that is, genes with above average variance 
A

A
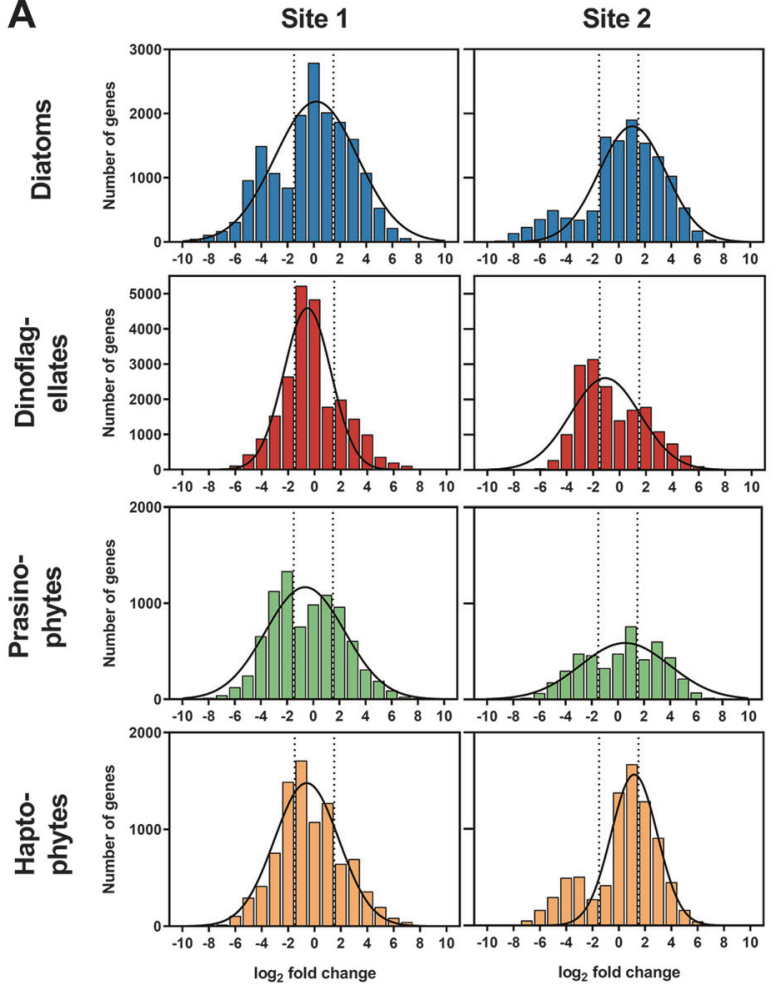

B
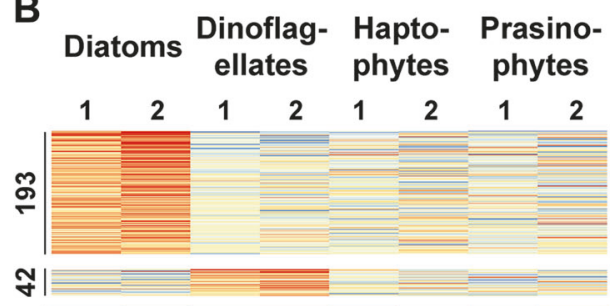

它|

$\bar{\infty} \mid$

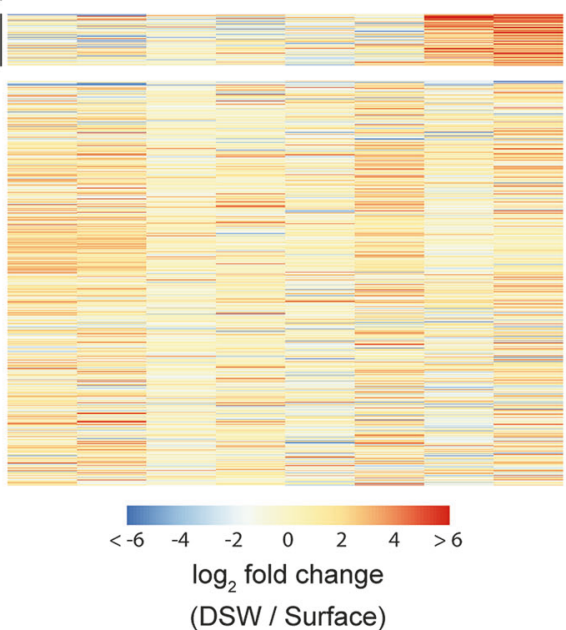

Fig. 5 Gene expression comparison among the four dominant eukaryotic phytoplankton groups at both experimental sites: diatoms (blue), dinoflagellates (red), prasinophytes (green), and haptophytes (orange). a Histograms of gene counts binned by $\log _{2}$ fold change intervals of 1 for the DSW treatment/surface treatment and fitted with a Gaussian curve. Dashed vertical lines indicate a $\log _{2}$ fold change of -1 or 1 . b Heatmap of KEGG Ortholog (KO) expression for the 1004 genes expressed by all four groups at both sites. Sites are denoted with the site number. Each row indicates an expressed KO with darker red

and fold change values greater than other groups. This pattern appears to continue when examining the diatom genes expressed by only one or two of the other examined groups (Fig. S8). Each group also had uniquely overrepresented orthologs; however, these numbered fewer than those of diatoms (42-81 genes).

Categorization of these uniquely overrepresented genes based on KEGG modules broadly shows the unique expression and transcriptional investments exhibited by each group (Fig. S9), although only 1787 (23.8\%) of the orthologs found here have a KEGG module categorization, which is expected from the database [27]. Diatoms expressed genes associated with photosynthesis, DNA repair and replication, sterol biosynthesis, and amino acid metabolism, which may correspond to their investments in growth and cell division-associated metabolic pathways and contribute to their increase in relative transcript proportions. Meanwhile, dinoflagellates and haptophytes expressed genes associated with glycan and fatty acid catabolism suggesting heterotrophy or higher reliance on intracellular compounds similar to observations of these same groups at (positive fold change) indicating overrepresentation in the DSW treatment and darker blue (negative fold change) indicating overrepresentation in the surface treatment. KOs were sorted based on average fold change values for each taxonomic group at both sites, having higher or lower fold change values than other taxonomic groups, and the variance in fold change values across all four groups being greater than the mean variance for the dataset. The number of genes uniquely overrepresented for a particular group in the DSW treatment is indicated on the left

depth and in the presence of prey $[71,72]$. Altogether, these distinctly overrepresented genes may represent some degree of niche partitioning with transcriptional investments in different cellular processes in response to nutrient amendment.

\section{Expression of nitrogen metabolism genes}

Genes involved in nitrogen assimilation and utilization were examined in all four dominant eukaryotic phytoplankton groups to investigate links between transcription and increases in particulate nitrogen and nitrate uptake rates (Figs. 3, 6, and S10). The nitrate uptake rates in both experiments indicate that both small and large size-fractions responded to the nutrient addition with increased rates of nitrate uptake; however, gene expression patterns suggest that not all four groups respond with the assimilatory nitrate reduction genes equivalently.

All groups but haptophytes at one site showed increased expression of nitrate transporters, and the greatest overrepresentation of nitrate transporters after nutrient 


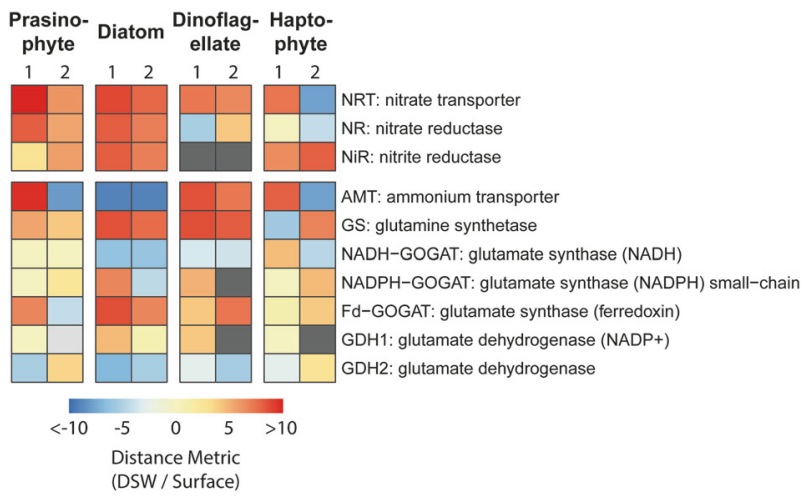

Fig. 6 Heatmap comparing the expression of nitrogen metabolism genes among the four dominant eukaryotic phytoplankton groups at both sites. Site numbers are denoted at the top of the heatmap. To account for both the abundance and change of gene expression, plotted values are the Euclidian distance of the $\log _{2}$ transformed mean abundance and fold change from 0 (DSW/Surface), i.e. no expression or change. Distances that are derived from negative fold change values are also shown as negative. Gray indicates no expression

amendment was observed in prasinophytes and diatoms. This corresponds to the observed increase in nitrate uptake rates within both size fractions, assuming the majority of prasinophytes were in the small size-fraction and diatoms were mostly in the large size-fraction. Diatoms, however, were the only group to consistently exhibit both high ( $>95$ th percentile of genes) and increased expression upon DSW amendment for the genes required for assimilatory nitrate reduction: nitrate transporter, nitrate reductase, and nitrite reductase. Prasinophytes showed comparatively low expression of nitrite reductase (43rd percentile at Site 1, 69th percentile at Site 2) and dinoflagellates displayed no detectable expression upon DSW amendment.

Results were inconsistent for nitrate reductase expression in dinoflagellates and haptophytes. Expression in both was reduced with DSW amendment at one of the two sites, and dinoflagellates increased expression at another site. At Site 1 , expression in haptophytes also increased but was very low (23rd percentile). Expression of ammonium transporters was also variable among the four groups. Within the DSW treatment, dinoflagellates showed increased gene expression whereas diatom expression decreased; haptophyte and prasinophyte expression patterns were inconsistent.

Although small eukaryotic phytoplankton have been found to be more reliant on nitrate compared to prokaryotes $[24,46]$, the differences here suggest that the proposed reliance on or utilization of nitrate among eukaryotes is not equivalent. First, the inconsistent expression of nitrate and nitrite reductases among phytoplankton groups suggests that eukaryotic phytoplankton groups may employ different strategies for nitrate assimilation. Nitrate is likely taken up by all groups based on the increased gene expression of nitrate transporters and nitrate uptake rates. Diatoms increased their expression of the entire pathway and likely channeled the assimilated nitrate towards growth, corresponding to increases in chlorophyll for the large size fraction and increases in the proportion of diatoms (Figs. 3 and 4). In contrast, the low expression of nitrite reductase in prasinophytes and dinoflagellates and of nitrate reductase in dinoflagellates and haptophytes suggests that these groups may exhibit a delayed response or shuttled nitrate towards storage rather than towards growth or short-term utilization. In the dinoflagellate Alexandrium minutum, it has been shown that most of the nitrate and ammonium taken up was stored rather than immediately utilized [73]. Nitrate storage has also been shown in the dinoflagellate Amphidinium carterae, the haptophyte Isochrysis galbana, and the chlorophyte Dunaliella tertiolecta although other species from the same lineages showed a lack of storage $[25,74]$. At least for the small $(<5 \mu \mathrm{m})$ phytoplankton, i.e. certain prasinophytes and haptophytes, these results may explain the maintenance of relatively high particulate nitrogen and nitrate uptake rates unmatched by increases in phytoplankton biomass (i.e., chlorophyll concentrations). Alternatively, timing of sampling may have resulted in the transcriptional response of these groups to be missed, although nitrate concentrations were still significantly higher in the DSW treatment compared to surface treatment $(P<0.05$; Fig. 2$)$. It is also plausible that diatoms are exhibiting some degree of nitrate storage as inferred by the overrepresentation of a putative vacuolar nitrate (CLC) transporter in the DSW treatment $(P=0.06)$ [75].

Secondly, dinoflagellates increased their expression of ammonium transporters, indicating a preference for ammonium even when nitrate was abundant which has also been observed in the laboratory for the dinoflagellate $A$. minutum (Fig. 6) [73]. In contrast, diatoms at both sites and haptophytes and prasinophytes at one site showed decreased expression of ammonium transporters. These differences in expression may be an example of niche partitioning by dinoflagellates to exploit regenerated forms of nitrogen as other groups, particularly diatoms, may be reducing their reliance on these recycled forms.

In dinoflagellates and diatoms, high expression of nitric oxide dioxygenase (NOD) was found at both sites. Dinoflagellates displayed high expression ( $>85$ th percentile) of this gene in both treatments while diatoms significantly expressed it in the surface treatment $\left(\log _{2}\right.$ fold change $>3$, $P<0.05$; Fig. 7). Phylogenetic analysis indicates that the gene was likely inherited via multiple horizontal gene transfer events, and that haptophytes also possess the gene although we did not detect haptophyte $N O D$ gene expression (Supplementary Text, Figs. S11 and S12). In prasinophytes, it was not identified.

NO in seawater likely only exists in low picomolar levels [76]. It can be produced abiotically via the photochemical 


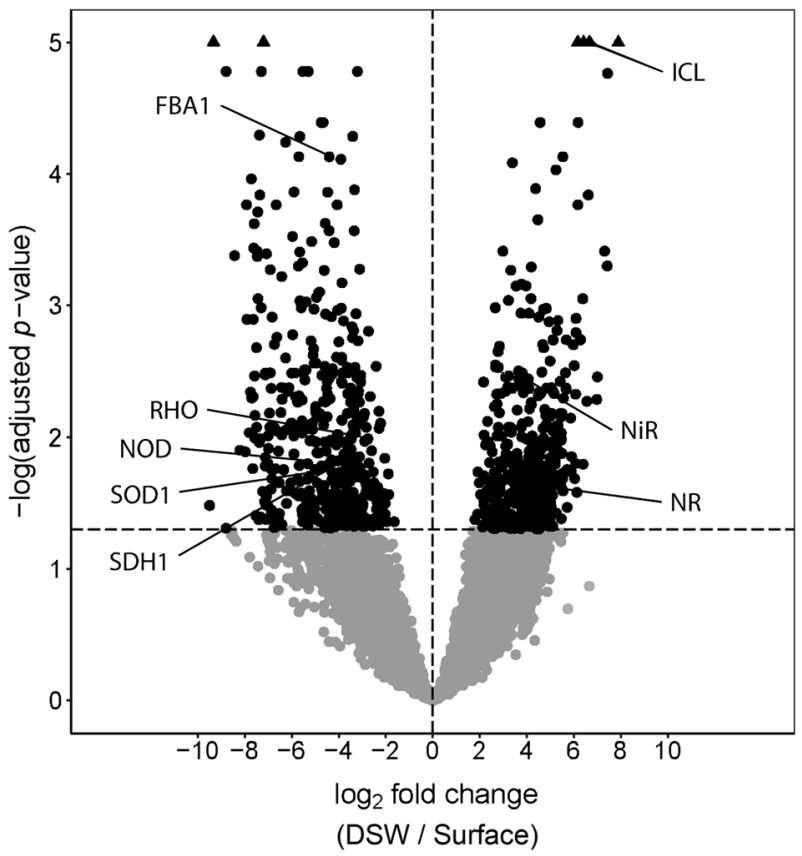

Fig. 7 Volcano plot of genes expressed by diatoms considering all surface and deep treatments from both experiments as replicates. The $\log _{2}$ fold changes (DSW vs. Surface) are displayed on the $x$-axis and the $-\log$ (adjusted $p$-values) are on the $y$-axis such that the most significantly expressed genes have greater values. Points with adjusted $p$ values $>0.05$ are below the horizontal dashed line in gray while points $>5\left(P<1 \times 10^{-5}\right)$ are plotted at 5 as black triangles. Labeled genes are abbreviated as follows: FBA1 fructose-bisphosphate aldolase, class I, ICL isocitrate lyase, NR nitrate reductase, NiR nitrite reductase, NOD nitric oxide dioxygenase, RHO proteorhodopsin, SDH succinate dehydrogenase, SOD1 $\mathrm{Cu}-\mathrm{Zn}$ superoxide dismutase

reduction of nitrite, but this is an unlikely source here as nitrite concentrations were also extremely low (Fig. 2) [77]. NO can also be produced via nitrate reductase activity or nitric oxide synthases as part of a stress surveillance system in diatoms or under lytic infection in haptophytes [78-81]; however, nitric reductase expression was lower in the surface treatment, and overall, nitric oxide synthase displayed relatively low gene expression or was absent in each of the main phytoplankton groups during this study.

Regardless of its synthesis from biotic or abiotic sources, NOD may play an important role in regulating the level of NO as a signaling molecule and thereby regulating the expression of nitrogen assimilation genes. In the model marine diatom, $P$. tricornutum, NOD is coexpressed with nitrate reductase suggesting that the two enzymes function to regulate nitrogen levels (nitrate, nitrite, and NO) which may control nitrogen assimilation gene expression [82]; however, strong opposing expression of $N O D$ and nitrate reductase was observed here (Fig. 7). The presence of NO in $P$. tricornutum has also been shown to upregulate nitrite reductase expression [81]; therefore, NOD may act to suppress $\mathrm{NO}$ and maintain lower expression of nitrite reductase consistent with our observations (Fig. S10). NOD also catalyzes the conversion of nitric oxide (NO) to nitrate with an associated oxidation of ferrous to ferric heme followed by a reduction back to the ferrous state by flavin adenine dinucleotide (FAD) [83, 84]. As the product of this reaction is nitrate, use of this gene may provide a small amount of additional nitrate from $\mathrm{NO}$ when nitrate concentrations are low and are limiting to phytoplankton growth similar to a role that has been suggested in raphidophytes [85].

\section{Diatom-specific gene expression}

Other significantly expressed genes in diatoms during these experiments may indicate certain cellular mechanisms that are utilized for their subsistence under typical oligotrophic conditions and for growth during periods of nutrient injection into the euphotic zone (Fig. 7). In examining both experiments, 904 genes showed significant differential expression (461 in the surface water treatment and 443 in the DSW treatment) (Dataset S4). This assessment includes genes that do not currently have an annotated function.

The genes overrepresented in the surface water treatments indicate how the diatom community is responding to long-term nitrogen-limited conditions. As expected, gene expression patterns indicate a reliance on regenerated forms of nitrogen as ammonium and urea transporters were highly expressed in the surface treatment (Fig. 8). Interestingly, transcript abundances of two genes that have been associated with low-iron conditions in diatoms, proteorhodopsin, and class I fructose-bisphosphate aldolase (FBA), were also significantly higher in the surface water treatment $(P<0.05)$ despite the relatively high iron concentrations that suggest iron availability was likely not limiting growth (Fig. 7) [86, 87]. Proteorhodopsin may serve as an alternative phototrophic mechanism while photosynthetic efficiency is reduced due to iron limitation [88]. Increased expression of proteorhodopsin in the surface water treatment also suggests that there may be other roles for the protein in diatoms in addition to coping with iron limitation. Class I FBAs are metal-independent functional equivalents of class II FBAs [89, 90]. Given that NOD requires Fe, utilization of low-iron-requiring pathways may reduce cellular $\mathrm{Fe}$ requirements to better support NOD activity; however, superoxide is required as well. A diatomassociated gene encoding $\mathrm{Cu}-\mathrm{Zn}$ superoxide dismutase was also significantly expressed $(P<0.05)$ (Fig. 7$)$, and the activity of superoxide dismutase would inhibit NOD activity.

In the DSW treatment, diatom transcription of many urea cycle genes were overrepresented, which is consistent with its known use for recovery from nitrogen limitation; however, some exceptions are apparent [91] (Fig. 8). Ornithine carbamoyltransferase showed nearly no change in expression between the two treatments. Urease showed reduced 


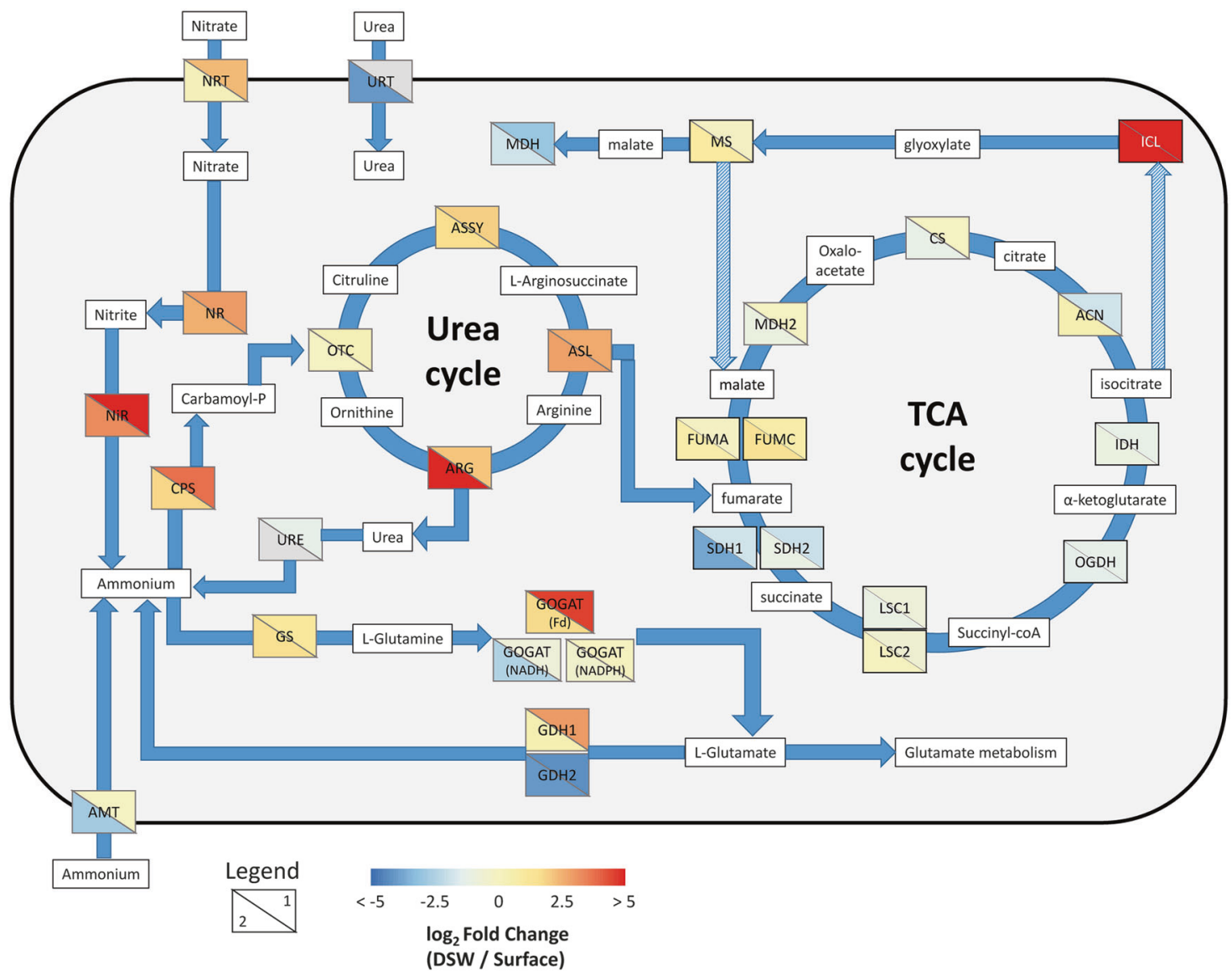

Fig. 8 Diatom cell schematic showing $\log _{2}$ fold change values for nitrogen metabolism and TCA cycle genes at sites 1 and 2 (see legend). Genes colored darker red (positive fold change) indicate overrepresentation in the DSW treatment and darker blue (negative fold change) indicate overrepresentation in the Surface treatment. Dashed arrows indicate uncharacterized transport as described by Davis et al. [94]. Genes are abbreviated as follows: ACN aconitase, AMT ammonium transporter, ARG arginase, ASL arginosuccinate lyase, ASSY arginosuccinate synthase, CPS carbamoyl phosphate

(Site 1) or no expression (Site 2) possibly indicating a delayed response until a sufficient amount of urea is generated (Fig. 8). As both ornithine and urea are products of arginase, ornithine could be used to produce putrescine for polyamine synthesis via ornithine decarboxylase at the time of sampling [92]. These ornithine-derived polyamines are important for cell wall biogenesis which would be important for diatom cell division [93]; transcripts for the gene encoding ornithine decarboxylase were highly abundant in the DSW treatment at Site 1 (fold change $=13.9, P=0.16$ ) but not at Site 2 .

Among the most significantly overrepresented genes in the DSW treatment was isocitrate lyase (Fig. $7, P<1 \times 10^{-7}$ ), suggesting that diatoms alter their carbon metabolism in response to the nutrient amendment and that the peroxisomal glyoxylate cycle plays an important role in this response [94]. Isocitrate lyase and malate synthase can create a bypass to the synthetase, CS citrate synthase, FUM fumarate hydratase, GS glutamine synthetase, GOGAT glutamate synthase, GDH glutamate dehydrogenase, ICL isocitrate lyase, IDH isocitrate dehydrogenase, LSC succinate-CoA ligase, MS malate synthase, MDH malate dehydrogenase, NRT nitrate transporter, NR nitrate reductase, NiR nitrite reductase, OGDH oxoglutarate dehydrogenase, OTC ornithine carbamoyltransferase, SDH succinate dehydrogenase, URT urea transporter, URE urease

tricarboxylic acid (TCA) cycle, which corresponds with decreases in expression in several TCA cycle genes (Figs. 7 and 8). This modification may help satisfy increased carbon demand as nitrogen assimilation increases. Increased expression of isocitrate lyase under nitrate replete conditions also aligns with laboratory studies examining nitrogen dynamics in $P$. tricornutum, although malate synthase was not differentially expressed in our study [95]. Isocitrate lyase has also been shown to be upregulated in diatoms under iron limitation $[82,90]$ indicating that the glyoxylate cycle may have more widespread importance under other nutritional scenarios.

\section{Conclusions}

Our metatranscriptomic analysis supports differing levels of transcriptional responsiveness among phytoplankton groups 
upon nutrient amendment in oligotrophic subtropical gyre systems [34]. Moreover, gene expression in conjunction with assessments of nutrient standing stocks and biological rate processes suggests that eukaryotic phytoplankton respond to injections of nitrate in different ways. Diatom gene expression patterns suggest newly acquired nitrate is rapidly assimilated and used to support growth, which partially explains the high level of diatom-driven export in the region. Meanwhile other phytoplankton groups may initially be storing the nitrate or relying on regenerated nitrogen forms. Further examination of nitrate storage across eukaryotic phytoplankton groups is warranted and could help provide context for these results.

Diatoms also coordinately alter their expression of other genes upon nutrient amendment which may support their increases in nitrogen assimilation. Ultimately, with most diatom genes lacking a functional annotation, it is likely that there are many cellular processes contributing to their survival and then subsequent growth upon nutrient delivery that are yet to be identified [13]. Furthermore, oligotrophic regions have been shown to have unexpectedly high diatom diversity implying that diatoms as a whole display a wide spectrum of growth strategies [96, 97]; thus, although we characterized a distinct diatom response here as a singular group, this observed response is likely driven by a dominant subset of diatoms while rarer species could be displaying other growth strategies more akin to the other phytoplankton functional groups. Further investigation into diatom diversity in the Sargasso Sea and other oligotrophic regions will be necessary to reveal the full spectrum of strategies.

A 15-year record of biogenic silica at BATS has found that diatom abundances are declining [98]. Corresponding increases in water column stratification and temperatures due to climate change suggests that increased nitrogen demand in eukaryotic phytoplankton [99] followed by less frequent delivery of subsurface nutrients could lead to a further decline. Our results indicate that diatoms are able to physiologically adjust their metabolism and employ mechanisms for survival under oligotrophic conditions, but it is possible that the limits of these mechanisms could soon be reached. Alternatively, diatom taxa and responses, such as those observed here may become more common as increased warming and vertical stratification expand oligotrophic subtropical gyre-like conditions to other regions of the ocean [100].

Acknowledgements We thank the captain and crew of the $R / V$ Atlantic Explorer and the participants of the cruise (AE1617). In particular, W. Tang (Duke), K. Ellis (UNC), and S. Gifford (UNC) provided much assistance with sample collection. Dissolved iron measurements were conducted by A. Gonzalez (LEMAR). R. Johnson (BIOS) provided materials, and S. Sugierski (UNC) assisted with sample processing and analysis. We also thank M. Lomas (Bigelow) for input on the experimental design. This work was funded by National Science
Foundation grants DGE-1650116 (Graduate Research Fellowship to RHL), OCE-1350710 (to NC), and OCE-1751805 (to AM); a Chateaubriand Fellowship (to SW); LabexMER grant ANR-10-LABX-19 (to $\mathrm{NC}$ ); and an Investissements d'Avenir grant from the French Government (to NC).

\section{Compliance with ethical standards}

Conflict of interest The authors declare that they have no conflict of interest.

Publisher's note: Springer Nature remains neutral with regard to jurisdictional claims in published maps and institutional affiliations.

\section{References}

1. McClain CR, Signorini SR, Christian JR. Subtropical gyre variability observed by ocean-color satellites. Deep-Sea Res II. 2004;51:281-301.

2. Steinberg DK, Carlson CA, Bates NR, Johnson RJ, Michaels AF, Knap AH. Overview of the US JGOFS Bermuda Atlantic Timeseries Study (BATS): a decade-scale look at ocean biology and biogeochemistry. Deep-Sea Res II. 2001;48:1405-47.

3. Lipschultz F. A time-series assessment of the nitrogen cycle at BATS. Deep-Sea Res II. 2001;48:1897-924.

4. Moore CM, Mills MM, Arrigo KR, Berman-Frank I, Bopp L, Boyd PW, et al. Processes and patterns of oceanic nutrient limitation. Nat Geosci. 2013;6:701.

5. Fawcett SE, Lomas MW, Ward BB, Sigman DM. The counterintuitive effect of summer-to-fall mixed layer deepening on eukaryotic new production in the Sargasso Sea. Glob Biogeochem Cycle. 2014;28:86-102.

6. Spitzer WS, Jenkins WJ. Rates of vertical mixing, gas exchange and new production: estimates from seasonal gas cycles in the upper ocean near Bermuda. J Mar Res. 1989;47:169-96.

7. Jenkins WJ. Studying subtropical thermocline ventilation and circulation using tritium and ${ }^{3} \mathrm{He}$. J Geophys Res-Oceans. 1998;103:15817-31.

8. Lomas MW, Bates NR, Johnson RJ, Knap AH, Steinberg DK, Carlson CA. Two decades and counting: 24-years of sustained open ocean biogeochemical measurements in the Sargasso Sea. Deep-Sea Res II. 2013;93:16-32.

9. Fawcett SE, Johnson KS, Riser SC, Van Oostende N, Sigman DM. Low-nutrient organic matter in the Sargasso Sea thermocline: a hypothesis for its role, identity, and carbon cycle implications. Mar Chem. 2018;20:108-23.

10. Nelson DM, Brzezinski MA. Diatom growth and productivity in an oligo-trophic midocean gyre: a 3-yr record from the Sargasso Sea near Bermuda. Limnol Oceanogr. 1997;42:473-86.

11. Agusti S, González-Gordillo JI, Vaqué D, Estrada M, Cerezo MI, Salazar G, et al. Ubiquitous healthy diatoms in the deep sea confirm deep carbon injection by the biological pump. Nat Commun. 2015;6:7608.

12. Krause JW, Nelson DM, Lomas MW. Biogeochemical responses to late-winter storms in the Sargasso Sea, II: Increased rates of biogenic silica production and export. Deep-Sea Res Pt I. 2009;56:861-74.

13. Bowler C, Vardi A, Allen AE. Oceanographic and biogeochemical insights from diatom genomes. Annu Rev Mar Sci. 2010;2:333-65.

14. Treusch AH, Demir-Hilton E, Vergin KL, Worden AZ, Carlson CA, Donatz MG, et al. Phytoplankton distribution patterns in the northwestern Sargasso Sea revealed by small subunit rRNA genes from plastids. ISME. J 2011;6:481. 
15. Marra J, Bidigare R, Dickey T. Nutrients and mixing, chlorophyll and phytoplankton growth. Deep Sea Res Part A. 1990;37:127-43.

16. Hansell DA, Carlson CA. Biogeochemistry of total organic carbon and nitrogen in the Sargasso Sea: control by convective overturn. Deep-Sea Res II. 2001;48:1649-67.

17. Orcutt KM, Lipschultz F, Gundersen K, Arimoto R, Michaels $\mathrm{AF}$, Knap AH, et al. A seasonal study of the significance of $\mathrm{N}_{2}$ fixation by Trichodesmium spp. at the Bermuda Atlantic Time-series Study (BATS) site. Deep-Sea Res Pt II. 2001;48:1583-608.

18. Knapp AN, Sigman DM, Lipschultz F. N isotopic composition of dissolved organic nitrogen and nitrate at the Bermuda Atlantic Time-series Study site. Glob Biogeochem Cycle. 2005;19: GB1018.

19. Knap A, Jickells T, Pszenny A, Galloway J. Significance of atmospheric-derived fixed nitrogen on productivity of the Sargasso Sea. Nature. 1986;320:158.

20. Altieri KE, Fawcett SE, Peters AJ, Sigman DM, Hastings MG. Marine biogenic source of atmospheric organic nitrogen in the subtropical North Atlantic. Proc Natl Acad Sci USA. 2016;113:925-30.

21. Lomas MW, Lipschultz F, Nelson DM, Krause JW, Bates NR. Biogeochemical responses to late-winter storms in the Sargasso Sea, I-Pulses of primary and new production. Deep-Sea Res I. 2009;56:843-60.

22. Hansell DA, Follows MJ. Nitrogen in the Atlantic Ocean. In: Capone DG, Bronk DA, Mulholland MR, Carpenter EJ, editors. Nitrogen in the marine environment. 2nd ed. Cambridge, MA: Academic Press; 2008. p. 597-630.

23. Stanley RHR, Jenkins WJ, Doney SC, Lott Iii DE. The ${ }^{3}$ He flux gauge in the Sargasso Sea: a determination of physical nutrient fluxes to the euphotic zone at the Bermuda Atlantic Time-series Site. Biogeosciences. 2015;12:5199-210.

24. Fawcett SE, Lomas MW, Casey JR, Ward BB, Sigman DM. Assimilation of upwelled nitrate by small eukaryotes in the Sargasso Sea. Nat Geosci. 2011;4:717.

25. Lomas MW, Glibert PM. Comparisons of nitrate uptake, storage, and reduction in marine diatoms and flagellates. J Phycol. 2000;36:903-13.

26. Lomas MW, Glibert PM. Temperature regulation of nitrate uptake: a novel hypothesis about nitrate uptake and reduction in cool-water diatoms. Limnol Oceanogr. 1999;44:556-72.

27. Lampe RH, Cohen NR, Ellis KA, Bruland KW, Maldonado MT, Peterson TD, et al. Divergent gene expression among phytoplankton taxa in response to upwelling. Environ Microbiol. 2018;20:3069-82.

28. Glibert PM, Wilkerson FP, Dugdale RC, Raven JA, Dupont CL, Leavitt PR, et al. Pluses and minuses of ammonium and nitrate uptake and assimilation by phytoplankton and implications for productivity and community composition, with emphasis on nitrogen-enriched conditions. Limnol Oceanogr. 2016;61:165-97.

29. Kudela RM, Dugdale RC. Nutrient regulation of phytoplankton productivity in Monterey Bay, California. Deep-Sea Res II. 2000;47:1023-53.

30. Alipanah L, Rohloff J, Winge P, Bones AM, Brembu T. Wholecell response to nitrogen deprivation in the diatom Phaeodactylum tricornutum. J Exp Bot. 2015;66:6281-96.

31. Matthijs M, Fabris M, Broos S, Vyverman W, Goossens A. Profiling of the early nitrogen stress response in the diatom Phaeodactylum tricornutum reveals a novel family of RINGdomain transcription factors. Plant Physiol. 2016;170:489-98.

32. Hockin NL, Mock T, Mulholland F, Kopriva S, Malin G. The response of diatom central carbon metabolism to nitrogen starvation is different from that of green algae and higher plants. Plant Physiol. 2012;158:299-312.
33. Bender S, Durkin C, Berthiaume C, Morales R, Armbrust EV. Transcriptional responses of three model diatoms to nitrate limitation of growth. Front Mar Sci. 2014;1:3.

34. Alexander H, Rouco M, Haley ST, Wilson ST, Karl DM, Dyhrman ST. Functional group-specific traits drive phytoplankton dynamics in the oligotrophic ocean. Proc Natl Acad Sci USA. 2015;112:E5972-E9.

35. Grabherr MG, Haas BJ, Yassour M, Levin JZ, Thompson DA, Amit I, et al. Full-length transcriptome assembly from RNA-Seq data without a reference genome. Nat Biotech. 2011;29:644-52.

36. Bolger AM, Lohse M, Usadel B. Trimmomatic: a flexible trimmer for illumina sequence data. Bioinformatics. 2014;30:2114-20.

37. Fu L, Niu B, Zhu Z, Wu S, Li W. CD-HIT: accelerated for clustering the next-generation sequencing data. Bioinformatics. 2012;28:3150-2.

38. Bertrand EM, McCrow JP, Moustafa A, Zheng H, McQuaid JB, Delmont TO, et al. Phytoplankton-bacterial interactions mediate micronutrient colimitation at the coastal Antarctic sea ice edge. Proc Natl Acad Sci USA. 2015;112:9938-43.

39. Kanehisa M, Furumichi M, Tanabe M, Sato Y, Morishima K. KEGG: new perspectives on genomes, pathways, diseases and drugs. Nucleic Acids Res. 2017;45:D353-D61.

40. Patro R, Duggal G, Love MI, Irizarry RA, Kingsford C. Salmon provides fast and bias-aware quantification of transcript expression. Nat Methods. 2017;14:417-9.

41. Love MI, Huber W, Anders S. Moderated estimation of fold change and dispersion for RNA-seq data with DESeq2. Genome Biol. 2014;15:550.

42. Brzezinski MA, Nelson DM. The annual silica cycle in the Sargasso Sea near Bermuda. Deep-Sea Res I. 1995;42:1215-37.

43. Tang W, Wang S, Fonseca-Batista D, Dehairs F, Gifford S, Gonzalez AG, et al. Revisiting the distribution of oceanic $\mathrm{N}_{2}$ fixation and estimating diazotrophic contribution to marine production. Nat Commun. 2019;10:831.

44. Eppley R. New production: history, methods, problems. In: Berger WH, Smetacek VS, Wefer G, editors. Productivity of the ocean: present and past. Hoboken, NJ: John Wiley and Sons; 1989. p. 85-97.

45. Glover HE, Garside C, Trees CC. Physiological responses of Sargasso Sea picoplankton to nanomolar nitrate perturbations. J Plankton Res. 2007;29:263-74.

46. Berthelot H, Duhamel S, L'Helguen S, Maguer JF, Wang S, Cetinić I, et al. NanoSIMS single cell analyses reveal the contrasting nitrogen sources for small phytoplankton. ISME J. 2019;13:651.

47. Kirchman DL, Wheeler PA. Uptake of ammonium and nitrate by heterotrophic bacteria and phytoplankton in the sub-Arctic Pacific. Deep-Sea Res I. 1998;45:347-65.

48. Allen AE, Booth MG, Frischer ME, Verity PG, Zehr JP, Zani S. Diversity and detection of nitrate assimilation genes in marine bacteria. Appl Environ Microb. 2001;67:5343-8.

49. de Baar HJW, Boyd PW, Coale KH, Landry MR, Tsuda A, Assmy P, et al. Synthesis of iron fertilization experiments: from the Iron Age in the age of enlightenment. J Geophys ResOceans. 2005;110:C09S16.

50. Landry M, Hassett R. Estimating the grazing impact of marine micro-zooplankton. Mar Biol. 1982;67:283-8.

51. Kamp A, Høgslund S, Risgaard-Petersen N, Stief P. Nitrate storage and dissimilatory nitrate reduction by eukaryotic microbes. Front Microbiol. 2015;6:1492.

52. Countway PD, Gast RJ, Dennett MR, Savai P, Rose JM, Caron DA. Distinct protistan assemblages characterize the euphotic zone and deep sea $(2500 \mathrm{~m})$ of the western North Atlantic (Sargasso Sea and Gulf Stream). Environ Microbiol. 2007;9:1219-32. 
53. Stoecker DK. Mixotrophy among Dinoflagellates. J Eukaryot Microbiol. 1999;46:397-401.

54. Li A, Stoecker DK, Adolf JE. Feeding, pigmentation, photosynthesis and growth of the mixotrophic dinoflagellate Gyrodinium galatheanum. Aquat Micro Ecol. 1999;19:163-76.

55. Cuvelier ML, Allen AE, Monier A, McCrow JP, Messié M, Tringe SG, et al. Targeted metagenomics and ecology of globally important uncultured eukaryotic phytoplankton. Proc Natl Acad Sci USA. 2010;107:14679-84.

56. Viprey M, Guillou L, Ferréol M, Vaulot D. Wide genetic diversity of picoplanktonic green algae (Chloroplastida) in the Mediterranean Sea uncovered by a phylum-biased PCR approach. Environ Microbiol. 2008;10:1804-22.

57. Tragin M, Vaulot D. Green microalgae in marine coastal waters: the Ocean Sampling Day (OSD) dataset. Sci Rep 2018;8:14020.

58. Malone T, Pike SE, Conley DJ. Transient variations in phytoplankton productivity at the JGOFS Bermuda time series station. Deep-Sea Res I. 1993;40:903-24.

59. Amin SA, Parker MS, Armbrust EV. Interactions between Diatoms and Bacteria. Microbiol. Mol Biol Rep. 2012;76:667-84.

60. Riley GA. Phytoplankton of the North Central Sargasso Sea, 1950-521. Limnol Oceanogr. 1957;2:252-70.

61. Hulburt EM. Description of phytoplankton and nutrient in spring in the western North Atlantic Ocean. J Plankton Res. 1990;12:1-28.

62. Siegel D, Iturriaga R, Bidigare R, Smith R, Pak H, Dickey T, et al. Meridional variations of the springtime phytoplankton community in the Sargasso Sea. J Mar Res. 1990;48:379-412.

63. Furnas MJ. In situ growth rates of marine phytoplankton: approaches to measurement, community and species growth rates. J Plankton Res. 1990;12:1117-51.

64. Edwards KF, Thomas MK, Klausmeier CA, Litchman E. Light and growth in marine phytoplankton: allometric, taxonomic, and environmental variation. Limnol Oceanogr. 2015;60:540-52.

65. Brzezinski MA, Krause JW, Church MJ, Karl DM, Li B, Jones JL, et al. The annual silica cycle of the North Pacific Subtropical Gyre. Deep-Sea Res. 2011;58:988-1001.

66. Wilson C, Qiu X. Global distribution of summer chlorophyll blooms in the oligotrophic gyres. Prog Oceanogr 2008;78:107-34.

67. Lin S. Genomic understanding of dinoflagellates. Res Microbiol. 2011;162:551-69.

68. Gong W, Browne J, Hall N, Schruth D, Paerl H, Marchetti A. Molecular insights into a dinoflagellate bloom. ISME J. 2017;11:439-52.

69. Cooper JT, Sinclair GA, Wawrik B. Transcriptome analysis of Scrippsiella trochoidea CCMP 3099 reveals physiological changes related to nitrate depletion. Front Microbiol. 2016;7:639.

70. Akbar M, Ahmad A, Usup G, Bunawan H. Current knowledge and recent advances in marine Dinoflagellate transcriptomic. Res J Mar Sci Eng. 2018;6:13.

71. Bjørnsen PK, Nielsen TG. Decimeter scale heterogeneity in the plankton during a pycnocline bloom of Gyrodinium aureolum. Mar Ecol Prog Ser. 1991;73:263-7.

72. Liu Z, Jones AC, Campbell V, Hambright KD, Heidelberg KB, Caron DA. Gene expression in the mixotrophic prymnesiophyte, Prymnesium parvum, responds to prey availability. Front Microbiol. 2015;6:319.

73. Maguer J, L'Helguen S, Madec C, Labry C, Le Corre P. Nitrogen uptake and assimilation kinetics in Alexandrium minutum (Dynophyceae): effect of N-limited growth rate on nitrate an ammonium interactions. J Phycol. 2007;43:295-303.

74. Dortch Q, Clayton JR, Thoresen SS, Ahmed SI. Species differences in accumulation of nitrogen pools in phytoplankton. Mar Biol. 1984;81:237-50.
75. McCarthy JK, Smith SR, McCrow JP, Tan M, Zheng H, Beeri K, et al. Nitrate reductase knockout uncouples nitrate transport from nitrate assimilation and drives repartitioning of carbon flux in a model pennate diatom. Plant Cell. 2017;29:2047-70.

76. Ward BB, Zafiriou OC. Nitrification and nitric oxide in the oxygen minimum of the eastern tropical North Pacific. Deep-Sea Res. 1988;35:1127-42.

77. Zafiriou OC, True MB. Nitrite photolysis as a source of free radicals in productive surface waters. Geophys Res Lett. 1979;6:81-4.

78. Vardi A, Bidle KD, Kwityn C, Hirsh DJ, Thompson SM, Callow $\mathrm{JA}$, et al. A diatom gene regulating nitric-oxide signaling and susceptibility to diatom-derived aldehydes. Curr Biol. 2008;18:895-9.

79. Vardi A, Formiggini F, Casotti R, De Martino A, Ribalet F, Miralto A, et al. A stress surveillance system based on calcium and nitric oxide in marine diatoms. PLoS Biol. 2006;4:e60.

80. Schieler BM, Soni MV, Brown CM, Coolen MJL, Fredricks H, Van Mooy BAS, et al. Nitric oxide production and antioxidant function during viral infection of the coccolithophore Emiliania huxleyi. ISME J. 2019;13:1019-31.

81. Dolch LJ, Lupette J, Tourcier G, Bedhomme M, Collin S, Magneschi L, et al. Nitric oxide mediates nitrite-sensing and acclimation and triggers a remodeling of lipids. Plant Physiol. 2017;175:1407-23.

82. Smith SR, Gillard JTF, Kustka AB, McCrow JP, Badger JH, Zheng H, et al. Transcriptional orchestration of the global cellular response of a model pennate diatom to diel light cycling under iron limitation. PLoS Genet. 2016;12:e1006490.

83. Forrester MT, Eyler CE, Rich JN. Bacterial flavohemoglobin: a molecular tool to probe mammalian nitric oxide biology. BioTechniques. 2011;50:41-5.

84. Gardner PR, Gardner AM, Martin LA, Salzman AL. Nitric oxide dioxygenase: an enzymic function for flavohemoglobin. Proc Natl Acad Sci USA. 1998;95:10378-83.

85. Stewart JJ, Coyne KJ. Analysis of raphidophyte assimilatory nitrate reductase reveals unique domain architecture incorporating a 2/2 hemoglobin. Plant Mol Biol. 2011;77:565-75.

86. Marchetti A, Schruth DM, Durkin CA, Parker MS, Kodner RB, Berthiaume CT, et al. Comparative metatranscriptomics identifies molecular bases for the physiological responses of phytoplankton to varying iron availability. Proc Natl Acad Sci USA. 2012;109:E317-E25.

87. Cohen NR, Ellis KA, Lampe RH, McNair HM, Twining BS, Brzezinski MA, et al. Variations in diatom transcriptional responses to changes in iron availability across ocean provinces. Front Mar Sci. 2017;4:360.

88. Marchetti A, Catlett D, Hopkinson BM, Ellis K, Cassar N. Marine diatom proteorhodopsins and their potential role in coping with low iron availability. ISME J. 2015;9:2745.

89. Allen AE, Moustafa A, Montsant A, Eckert A, Kroth PG, Bowler C. Evolution and functional diversification of fructose bisphosphate aldolase genes in photosynthetic marine diatoms. Mol Biol Evol. 2012;29:367-79.

90. Lommer M, Specht M, Roy A-S, Kraemer L, Andreson R, Gutowska MA, et al. Genome and low-iron response of an oceanic diatom adapted to chronic iron limitation. Genome Biol. 2012;13:R66.

91. Allen AE, Dupont CL, Obornik M, Horak A, Nunes-Nesi A, McCrow JP, et al. Evolution and metabolic significance of the urea cycle in photosynthetic diatoms. Nature. 2011;473:203-7.

92. Michael AJ. Molecular machines encoded by bacterially-derived multi-domain gene fusions that potentially synthesize, Nmethylate and transfer long chain polyamines in diatoms. FEBS Lett. 2011;585:2627-34. 
93. Kröger N, Poulsen N. Diatoms-from cell wall biogenesis to nanotechnology. Annu Rev Genet. 2008;42:83-107.

94. Davis A, Abbriano R, Smith SR, Hildebrand M. Clarification of photorespiratory processes and the role of malic enzyme in diatoms. Protist. 2017;168:134-53.

95. Yang ZK, Niu YF, Ma YH, Xue J, Zhang MH, Yang WD, et al. Molecular and cellular mechanisms of neutral lipid accumulation in diatom following nitrogen deprivation. Biotechnol Biofuels. 2013;6:67.

96. Malviya S, Scalco E, Audic S, Vincent F, Veluchamy A, Poulain J, et al. Insights into global diatom distribution and diversity in the world's ocean. Proc Natl Acad Sci USA. 2016;113:E1516-E25.
97. Kemp AES, Villareal TA. The case of the diatoms and the muddled mandalas: Time to recognize diatom adaptations to stratified waters. Prog Oceanogr. 2018;167:138-49.

98. Krause JW, Lomas MW, Nelson DM. Biogenic silica at the Bermuda Atlantic Time-series Study site in the Sargasso Sea: temporal changes and their inferred controls based on a 15-year record. Global Biogeochem Cycles. 2009;23:GB3004.

99. Toseland A, Daines SJ, Clark JR, Kirkham A, Strauss J, Uhlig C, et al. The impact of temperature on marine phytoplankton resource allocation and metabolism. Nat Clim Change. 2013;3:979.

100. Polovina JJ, Howell EA, Abecassis M. Ocean's least productive waters are expanding. Geophys Res Lett. 2008;35:L03618. 